\section{Airblast Application of Copper Fungicide to Grapefruit Does Not Affect Windscar}

\author{
Ed Stover, ${ }^{1}$ Jack Hebb, and Ron Sonoda \\ University of Florida, Fort Pierce, FL 34945 \\ Masoud Salyani \\ University of Florida, Lake Alfred, FL 33850
}

Additional index words. aerial spraying, Citrus paradisi, copper hydroxide, cullage, Diaporthe citri, fungicide, grapefruit, Indian River, melanose, phytotoxicity, wind velocity

Abstract. Wind-induced blemishing known as windscar and lesions from the disease melanose (caused by Diaporthe citri) are two of the most important causes of fresh grapefruit (Citrus paradisi) cullage in Florida. Copper hydroxide fungicides are the primary means of controlling melanose, but high air velocities from passing sprayers have been suspected of increasing windscar. In 1998 and 1999, airblast applications of $\mathrm{Cu}(\mathrm{OH})_{2}\left(1.7 \mathrm{~kg} \cdot \mathrm{ha}^{-1}\right.$ $\mathrm{Cu}$ ) were made at a range of early fruit development stages to a fresh grapefruit orchard in the Indian River region of Florida. These applications supplemented aerial sprays of $\mathrm{Cu}(\mathrm{OH})_{2}$ that were made uniformly across the entire experimental site at biweekly intervals beginning near full bloom. During the commercial harvest period fruit were sampled from three regions (interior, upper exterior, and lower exterior) of each treatment tree and were evaluated for percentage of fruit surface covered by windscar and severity of melanose. Airblast applications did not affect windscar in either year, but windscar was significantly greater from the upper exterior of the canopy, which is likely to experience the highest natural wind velocities. From these data, it appears unlikely that airblast applications significantly contribute to windscar of Indian River grapefruit. In 1998, no trees receiving airblast applications had significantly lower melanose incidence than the trees sprayed only via aircraft; however, trees receiving four airblast applications were scored as having higher apparent melanose on exterior samples than trees receiving most other treatments. This is consistent with high levels of $\mathrm{Cu}$ injury on these fruit which can superficially resemble melanose. Following treatment in 1999, trees receiving four airblast applications of $\mathrm{Cu}(\mathrm{OH})$, had significantly lower melanose scores than trees receiving either no or only early airblast applications, but were not significantly different from trees receiving a single spray 5.5 weeks postbloom. A computer model, which estimates $\mathrm{Cu}$ levels on fruit based on fruit growth, rainfall, and application parameters, indicated exterior fruit receiving four airblast sprays had $>3 \mu \mathrm{g} \cdot \mathrm{cm}^{-2}[\mathrm{Cu}]$ for $\mathbf{4 0}$ days in 1998 but only 10 days in 1999, which reflects increased probability of Cu damage in 1998. It appears that aerial application supplemented by airblast merits further study as an economical means of melanose control.

Fresh-market grapefruit (Citrus paradisi) production in the Indian River region of Florida requires use of cultural practices that reduce fruit blemish. Several diseases affecting rind appearance are important causes of grapefruit cullage (Miller and Burns, 1992), and are primarily controlled with fungicides. One of these diseases, melanose (caused by Diaporthe citri), can infect fruit from initial set until they are 6 to $7 \mathrm{~cm}$ in diameter (Timmer, 2001). Typically, two applications of $\mathrm{Cu}(\mathrm{OH})_{2}$ at high rates (4.5 to $11.4 \mathrm{~kg} \mathrm{Cu} / \mathrm{ha}$ ) have been used during the infection period (Kucharek and Brown, 1992), but recent studies indicate that more frequent application with lower doses of $\mathrm{Cu}$ fungicides $(2.2 \mathrm{~kg}$ metallic $\mathrm{Cu} / \mathrm{ha}$ ) may more effectively control melanose (Timmer et al., 1998). Unfortunately, sprayer capacity

Received for publication 8 Nov. 2002. Accepted for publication 19 June 2003. Florida Agricultural Experiment Station Journal Series No. R-09170.

${ }^{1}$ To whom correspondence should be addressed;
Phenological stages at which melanose develops on fruit correspond to the 12-week postbloom period when fruit are also most susceptible to wind-induced mechanical damage (Dodson, 1966). Such damage is commonly known as windscar (Albrigo, 1976), and is often the most important cause of fresh fruit cullage in Florida grapefruit (Miller and Burns, 1992). Metcalf (1936) reported windscar in citrus from wind velocity as low as $6.7 \mathrm{~m} \cdot \mathrm{s}^{-1}$. Airblast sprayers, the most common means of applying foliar agrochemicals to grapefruit (Stover et al., 2002b), produce initial wind velocities of 36 to $67 \mathrm{~m} \cdot \mathrm{s}^{-1}$ (Valco and O'Neal, 2002), creating concern that spraying may contribute to windscar (McPhee, 1966; Indian River citrus growers, personal communication).

The purpose of these experiments was twofold. The first was to assess the effect of airblast spraying on windscar development, and the second to assess melanose protection from supplemental airblast applications on an aerially sprayed orchard, both during a range of fruit development stages.

\section{Materials and Methods}

Trees used and spray applications. Trials were conducted in a mature commercial block of 'Ruby' grapefruit on sour orange rootstock in Ft. Pierce, Fla., which was maintained for fresh fruit production. Before the initiation of this study, the block displayed consistent moderate levels of melanose infection on fruit, leaves and twigs typical of mature Indian River grapefruit. Standard commercial production practices were conducted uniformly across the experimental site except that the only sprays applied with tractor-drawn equipment were the described experimental treatments. All $\mathrm{Cu}(\mathrm{OH})_{2}$, applications were made using $1.7 \mathrm{~kg} \cdot \mathrm{ha}^{-1}$ metallic $\mathrm{Cu}$ (Kocide 2000; Griffin LLC, Valdosta, Ga.). Copper hydroxide applications were made uniformly across the entire experimental site at biweekly intervals beginning at full bloom in 1998 and 1 week post-full bloom in 1999 (Table 1). Aircraft used was an AT-502 (Air Tractor, Inc., Olney, Tex.) with sprays applied at $140 \mathrm{~L} \cdot \mathrm{ha}^{-1}$, using Micronair AU-3000 (Micron Sprayers, Ltd., Bromyard, Herefordshire, U.K.) rotary atomizers. This uniform aerial application was supplemented with ground applications to selected trees at designated times (Table 2). The experiment was established using a randomized complete block design with six three-tree replications per treatment which were blocked spatially throughout the field. Buffer trees were used between and within rows to prevent overspray $\begin{array}{ll}\text { aerial application at crucial periods may be an } & \text { of treatment trees from ground applied treat- } \\ \text { economic compromise. } & \text { ments. A sprayer (FMC 957 High Back; John }\end{array}$ $\begin{array}{ll}\text { aerial application at crucial periods may be an } & \text { of treatment trees from ground applied treat- } \\ \text { economic compromise. } & \text { ments. A sprayer (FMC 957 High Back; John }\end{array}$ Table 1. Calendar date and time relative to bloom for 1998 applications of $\mathrm{Cu}(\mathrm{OH})_{2}$ at $1.7 \mathrm{~kg} \cdot \mathrm{ha}^{-1}$ metallic $\mathrm{Cu}$, to mature 'Ruby' grapefruit in Ft. Pierce, Fla.

\begin{tabular}{llll}
\hline $\begin{array}{l}\text { Stage of } \\
\text { development }\end{array}$ & $\begin{array}{l}\text { Date of aerial } \\
\text { spray 1998 }\end{array}$ & $\begin{array}{l}\text { Stage of } \\
\text { development }\end{array}$ & $\begin{array}{l}\text { Date of ground } \\
\text { spray 1998 }\end{array}$ \\
\hline $\begin{array}{l}\text { Full bloom } \\
\text { Postbloom }\end{array}$ & 3 Apr. & Full bloom & 2 Apr. \\
2 weeks & 17 Apr. & Postbloom, 3 weeks & 27 Apr. \\
4 weeks & 6 May & Postbloom, 5.5 weeks & 13 May \\
6 weeks & 20 May & Postbloom, 8 weeks & \\
9 weeks & 15 June & & \\
\hline
\end{tabular}

HortScience Vol. 39(3) June 2004 
Table 2. Calendar date and time relative to bloom for 1999 applications of $\mathrm{Cu}(\mathrm{OH})_{2}$ at $1.7 \mathrm{~kg} \cdot \mathrm{ha}^{-1}$ metallic $\mathrm{Cu}$, to mature 'Ruby' grapefruit in Ft. Pierce, Fla.

\begin{tabular}{|c|c|c|c|}
\hline $\begin{array}{l}\text { Stage of } \\
\text { development }\end{array}$ & $\begin{array}{l}\text { Date of aerial } \\
\text { spray } 1999\end{array}$ & $\begin{array}{l}\text { Stage of } \\
\text { development }\end{array}$ & $\begin{array}{l}\text { Date of ground } \\
\text { spray } 1999\end{array}$ \\
\hline Postbloom 1 week & 26 Apr. & Full bloom & 19 Apr. \\
\hline 3 weeks & 12 May & Postbloom, 3 weeks & 11 May \\
\hline 5.5 weeks & 27 May & Postbloom, 5.5 weeks & 27 May \\
\hline 7 weeks & 9 June & Postbloom, 8 weeks & 17 June \\
\hline 9 weeks & 25 June & & \\
\hline
\end{tabular}

Table 3. Mean and maximum sprayer-generated air velocity at different locations in the canopy of mature 'Ruby' grapefruit near Ft. Pierce, Fla. The sprayer tested was the FMC 957 High Back used for all aspects of this report.

\begin{tabular}{llcc}
\hline & Sample $^{\mathrm{z}}$ & & \multicolumn{2}{c}{ Air velocity $^{\mathrm{y}}$} \\
\cline { 4 - 5 } $\begin{array}{l}\text { Canopy } \\
\text { position }\end{array}$ & $\begin{array}{c}\mathrm{Ht} \\
(\mathrm{m})\end{array}$ & $\begin{array}{c}\text { Mean } \\
\left(\mathrm{m} \cdot \mathrm{s}^{-1}\right)\end{array}$ & $\begin{array}{c}\text { Max } \\
\left(\mathrm{m} \cdot \mathrm{s}^{-1}\right)\end{array}$ \\
\hline Exterior & 1.5 & $2.85(0.09)$ & $9.02(0.73)$ \\
Exterior & 3 & $3.30(0.30)$ & $8.34(0.48)$ \\
Center & 1.5 & $1.30(0.20)$ & $2.24(0.45)$ \\
Center & 3 & $1.14(0.12)$ & $1.83(0.24)$ \\
Overall & & $2.15(0.52)$ & $5.36(1.80)$ \\
\hline
\end{tabular}

${ }^{2}$ Exterior $=$ periphery of canopy, center $=$ center of canopy.

${ }^{\mathrm{y}}$ Mean (standard error of the mean).
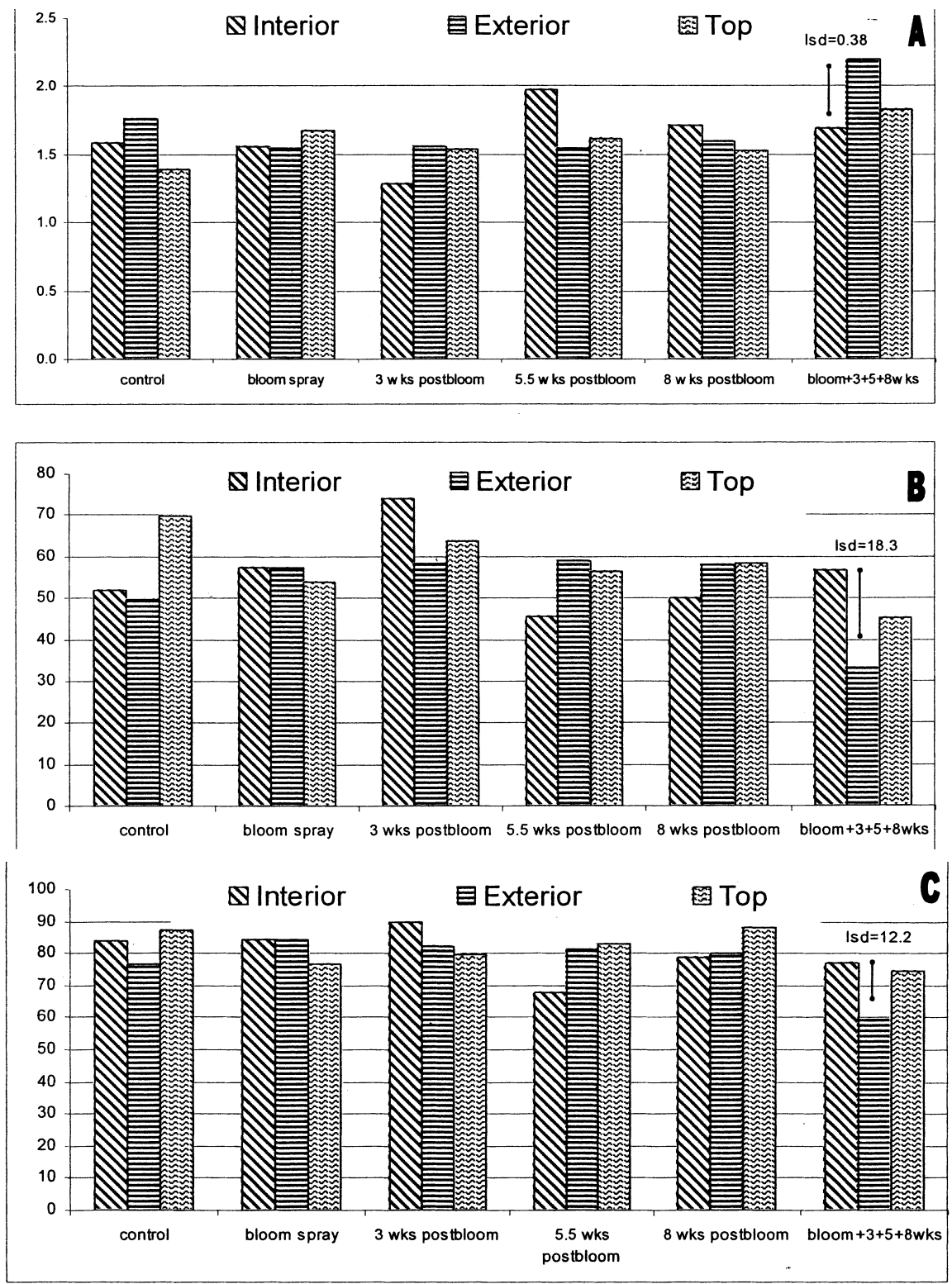

Fig. 1. Interaction between airblast spray timing and canopy position for $(\mathbf{A})$ melanose score, $(\mathbf{B})$ percentage of fruit with a melanose score of $<2$, and $(\mathbf{C})$ percentage of fruit with a melanose score of $<3$.
Bean Sprayers, Hogansville, Ga.) equipped withAlbuz nozzles (Saint-Gobain Ceramiques, Vincennes, France) was used to deliver 2300 $\mathrm{L} \cdot \mathrm{ha}^{-1}$ at $0.9 \mathrm{~m} \cdot \mathrm{s}^{-1}$ ground speed and 1035 $\mathrm{kPa}$ pressure. The PTO speed was increased on the buffer tree before each replication, to achieve designated pressure, and decreased immediately after each sprayed replication so that the axial fan delivered minimal wind on trees that were not treated on each designated spray date.

Fruit sampling and assessment. During the period of commercial harvest 40 to 60 fruit of commercial size $(1 \mathrm{Fla}$. field box $=56 \mathrm{~L})$ were randomly harvested (1 Oct. 1998 and 18 Jan. 2000) from each of three zones (interior: region from tree trunk through $0.5 \mathrm{~m}$ from exterior of canopy at 0.5 to $3.0 \mathrm{~m}$ height; exterior: outer 0.5 $\mathrm{m}$ of tree canopy from 0.5 to $3.0 \mathrm{~m}$ height; top: outer $0.5 \mathrm{~m}$ of tree canopy above $3.0 \mathrm{~m}$ height) in each replication. Fruit were washed and individually evaluated for percentage of fruit surface covered by windscar and for severity of melanose. Melanose was assessed on a 5-point scale, with $0=$ no spots, $1=1$ to 15 spots on the most severely affected fruit hemisphere, 2 $=\approx 16$ to 30 spots, $3=\approx 31$ to 60 spots, and $4=$ $\geq 61$ spots. Spots were scored as melanose when they were raised (Whiteside, 1988) and could not be removed by scraping with a fingernail It is now reported that marks from $\mathrm{Cu}$ toxicity on grapefruit can sometimes be very similar in appearance to melanose (Stover et al., 2002a) and it is likely that such spots were sometimes included in the melanose score. Melanose severity was analyzed as mean score for assessed fruit, percentage of fruit scoring $<2$, and percentage of fruit scoring $<3$. These thresholds were used because Indian River packinghouse managers (personal communication) indicate that export shipments require fruit scoring $<2$ on the melanose scale, while most domestic markets reject fruit scoring $\geq 3$.

Statistical analysis of fruit marking by windscar and melanose. Data were analyzed by ANOVA using ProcGLM (SAS Institute, Cary, N.C.). Where the treatments were found significantly different at $p \leq 0.05$, means were separated using DMRT. Percentage data were found to diverge slightly from a normal distribution but were not heterogeneous for variance by Levene's test and so were analyzed without transformation.

Sprayer-generated air velocity. Sprayer produced air velocity was measured at the exterior and center of the tree canopy at 1.5 and $3.0 \mathrm{~m}$ heights in each of three study trees. Measurements were made using a FlowMaster precision anemometer (Dantec Measurement Technology, Skovlunde, Denmark). Mean and maximum sprayer air velocities are presented for each canopy position (Table 3).

Estimating $\mathrm{Cu}$ residues. To help explain observed melanose scores, a computer mode was used to estimate peel $\mathrm{Cu}$ residues on exterior grapefruit (Lin et al., 1999). This expert system models $\mathrm{Cu}$ levels on fruit surfaces as a function of $\mathrm{Cu}$ application parameters, fruit growth, and rainfall and is designed to help growers optimize use of $\mathrm{Cu}(\mathrm{OH})$

HorTSCIENCE Vol. 39(3) June 2004 
Table 4. Effect of time of $\mathrm{Cu}(\mathrm{OH})_{2}$ application by ground-driven airblast sprayer and canopy position of sampled fruit on melanose and windscar in mature 'Ruby' grapefruit near Ft. Pierce, Fla., in 1998.

\begin{tabular}{|c|c|c|c|c|c|c|c|}
\hline $\begin{array}{l}\text { Airblast spray } \\
\text { timing }\end{array}$ & $\begin{array}{l}\text { Canopy } \\
\text { position }\end{array}$ & $\begin{array}{c}\text { Mean windscar } \\
(\% \text { of fruit surface })\end{array}$ & $\begin{array}{c}\text { Fruit }<5 \% \\
\text { windscar }(\%)\end{array}$ & $\begin{array}{c}\text { Fruit }<10 \% \\
\text { windscar }(\%)\end{array}$ & $\begin{array}{c}\text { Mean melanose } \\
\text { score }^{z}\end{array}$ & $\begin{array}{c}\text { Fruit }<2 \text { melanose } \\
\text { score }(\%)\end{array}$ & $\begin{array}{c}\text { Fruit }<3 \text { melanose } \\
\text { score }(\%)\end{array}$ \\
\hline & Exterior & $5.2 \mathrm{a}$ & $55.9 \mathrm{a}$ & $82.5 \mathrm{a}$ & 1.6 & 55.9 & 80.3 \\
\hline & Top & $6.5 \mathrm{~b}$ & $45.1 \mathrm{~b}$ & $74.6 \mathrm{~b}$ & 1.6 & 57.9 & 81.6 \\
\hline Bloom & & 5.3 & 53.6 & 83.1 & $1.59 \mathrm{a}$ & $56.1 \mathrm{ab}$ & $81.8 \mathrm{a}$ \\
\hline \multicolumn{8}{|l|}{ Postbloom } \\
\hline 3 weeks & & 5.8 & 51.0 & 78.9 & $1.46 \mathrm{a}$ & $65.4 \mathrm{a}$ & $83.8 \mathrm{a}$ \\
\hline
\end{tabular}

${ }^{2}$ Melanose was scored on a 5-point scale with $0=$ no spots, $1=1$ to 15 spots on the most severely marked fruit hemisphere, 2 is $\approx 16$ to 30 spots, 3 is $\approx 31$ to 60 spots, and 4 is $\approx 61$ or more spots. Spots were scored as melanose when they were raised and could not be removed by scraping with a fingernail, but results suggest that some $\mathrm{Cu}$ marking of fruit was scored as melanose.

${ }^{y}$ DMRT mean separations are only provided for data found significantly different by ANOVA. Means within a column not followed by the same letter were found significantly different by DMRT at $p \leq 0.05$. Comparisons can only be made among different canopy positions or airblast timings and not between position and timing data.

Table 5. Effect of time of $\mathrm{Cu}(\mathrm{OH})_{2}$ application by ground-driven airblast sprayer and canopy position of sampled fruit on melanose and windscar in mature 'Ruby' grapefruit near Ft. Pierce, Fla., in 1999-2000.

\begin{tabular}{|c|c|c|c|c|c|c|c|}
\hline $\begin{array}{l}\text { Airblast spray } \\
\text { timing }\end{array}$ & $\begin{array}{l}\text { Canopy } \\
\text { position }\end{array}$ & $\begin{array}{l}\text { Mean windscar } \\
(\% \text { of fruit surface })\end{array}$ & $\begin{array}{c}\text { Fruit }<5 \% \\
\text { windscar }(\%)\end{array}$ & $\begin{array}{l}\text { Fruit }<10 \% \\
\text { windscar }(\%)\end{array}$ & $\begin{array}{l}\text { Mean melanose } \\
\text { score }^{z}\end{array}$ & $\begin{array}{c}\text { Fruit }<2 \text { melanose } \\
\text { score }(\%)\end{array}$ & $\begin{array}{c}\text { Fruit }<3 \text { melanose } \\
\text { score }(\%)\end{array}$ \\
\hline & Exterior & $4.5 \mathrm{~b}$ & $67.3 \mathrm{~b}$ & $87.5 \mathrm{a}$ & $1.6 \mathrm{~b}$ & $63.6 \mathrm{~b}$ & $86.3 \mathrm{~b}$ \\
\hline & Top & $5.7 \mathrm{c}$ & $55.1 \mathrm{c}$ & $80.7 \mathrm{~b}$ & $1.4 \mathrm{a}$ & $72.8 \mathrm{a}$ & $89.7 \mathrm{a}$ \\
\hline Bloom & & 4.3 & 68.9 & 86.3 & $1.83 \mathrm{c}$ & $50.6 \mathrm{c}$ & $77.4 \mathrm{c}$ \\
\hline \multicolumn{8}{|l|}{ Postbloom } \\
\hline 3 weeks & & 4.4 & 65.9 & 86.6 & $1.62 \mathrm{abc}$ & $63.3 \mathrm{ab}$ & $82.4 \mathrm{bc}$ \\
\hline Bloom $+3+5$ & $5+8$ weeks & 4.6 & 63.4 & 85.4 & $1.38 \mathrm{a}$ & $71.9 \mathrm{a}$ & $91.5 \mathrm{a}$ \\
\hline
\end{tabular}

${ }^{2}$ Melanose was scored on a 5-point scale with $0=$ no spots, $1=1$ to 15 spots on the most severely marked fruit hemisphere, $2=\approx 16$ to 30 spots, $3=\approx 31$ to 60 spots, and $4=\approx 61$ or more spots. Spots were scored as melanose when they were raised and could not be removed by scraping with a fingernail, but results suggest that some $\mathrm{Cu}$ marking of fruit was scored as melanose.

yDMRT mean separations are only provided for data found significantly different by ANOVA. Means within a column not followed by the same letter were found significantly different by DMRT at $p \leq 0.05$. Comparisons can only be made among different canopy positions or airblast timings and not between position and timing data. ${ }^{2}$ Spray contractor erroneously applied $\mathrm{Cu}(\mathrm{OH})_{2}$ at bloom as well as 8 weeks postbloom.

\section{Results and Discussion}

Interactions between airblast timings and sampling positions. The interaction between airblast timing and sampling position was significant for melanose rating in 1998 but not for windscar, and no significant interaction was observed in 1999. A major source of this interaction was high melanose-like $\mathrm{Cu}$ injury on exterior and top samples from trees receiving four airblast applications of $\mathrm{Cu}(\mathrm{OH})$ in 1998. On these trees, exterior fruit had $40 \%$ higher mean melanose score compared to trees receiving all other spray treatments (Fig. 1A). As a result, the trees receiving four airblast applications had significantly higher melanose scores than trees of most other treatments when averaged across sample position (Table 4). These results are consistent with recent reports that $\mathrm{Cu}$ application sometimes produces a $\mathrm{Cu}$ burn that is superficially similar to melanose (Stover et al., 2002a)

Use of an expert system to predict $\mathrm{Cu}$ levels on fruit surfaces (Lin et al., 1999) indicated that exterior fruit receiving four airblast sprays had $>3 \mu \mathrm{g} \cdot \mathrm{cm}^{-2}[\mathrm{Cu}]$ for $40 \mathrm{~d}$ in 1998 , but only 10 $\mathrm{d}$ in 1999 (data not shown). These high levels of $\mathrm{Cu}$ were projected for most of the period between 10 May and 17 June 1998, during which there were only two significant rain events (Fig. 2). It is likely that this prolonged period of high $\mathrm{Cu}$ residue increased risk of



Fig. 2. Rainfall distribution recorded by weather station within $3 \mathrm{~km}$ of experimental site.

phytotoxic response. Because the significant interaction can be explained, and discussion of main effects provides a more meaningful interpretation of results, main effects of airblast spray timing and sampling position are the focus of this report.

Windscar. Airblast spray treatments did not inrease windscar of grapefruit in either year of this study (Tables 4 and 5). In both years, great- est windscar was observed in fruit from tree tops where natural wind velocity is expected to be highest, since neighboring trees provide a windbreak for the lower canopy. In 1999-2000 but not in 1998, windscar was less for fruit harvested from the tree interior as compared to that from the lower exterior. Although air velocities generated by the sprayer were in the range reported to produce windscar (Metcalf, 
1936), velocities measured in the canopy were much lower than might be anticipated based on air velocities issuing from sprayer air outlets. Maximum sprayer-generated air velocities of 9.0 (at $1.5 \mathrm{~m}$ height on the exterior canopy) and 8.3 $\mathrm{m} \cdot \mathrm{s}^{-1}$ (at $3.0 \mathrm{~m}$ height on the exterior canopy) (Table 3 ) were within the range of maximum wind velocities recorded at the Ft. Pierce weather station for the study period $\left(11.8 \mathrm{~m} \cdot \mathrm{s}^{-1}\right.$ in 1998 and $9.4 \mathrm{~m} \cdot \mathrm{s}^{-1}$ in $1999 ; \mathrm{FAWN}, 2002$ ). Data from this station indicated that from 30 Apr. to 15 July 1998 (data set is incomplete due to equipment failure), there were $14 \mathrm{~h}$ with a maximum velocity greater than the $6.7 \mathrm{~m} \cdot \mathrm{s}^{-1}$ reported to cause windscar in citrus (Metcalf, 1936), and $7 \mathrm{~h}$ in which the hourly average wind velocity exceeded this value. From 1 Apr. to 15 July 1999 , there were $38 \mathrm{~h}$ with a maximum wind velocity $>6.7 \mathrm{~m} \cdot \mathrm{s}^{-1}$ and $9 \mathrm{~h}$ in which the hourly average velocity exceeded this value (FAWN, 2002). It should be noted that the sprayer used in this study generated air velocities typical of those produced by commercial sprayers in citrus canopies (Salyani et al., 2000). These data suggest that transient passage of a sprayer is unlikely to significantly affect windscar in Florida citrus.

Melanose. Melanose scores did not differ among fruit sampling positions in 1998, even though most melanose results from pycnidiospores produced on dead twigs and these spores spread only short distances (Whiteside, 1988), resulting in highest incidence of true melanose on interior fruit, even in unsprayed trees (E. Stover, unpublished data). As described above, reported melanose scores in 1998 were probably increased by melanose-like $\mathrm{Cu}$ burn on fruit from the tree exterior and top samples. In 1999-2000, melanose scores and percentage of fruit exceeding thresholds for cullage were lowest for fruit sampled from tree tops, generally intermediate for lower exterior fruit, and greatest for fruit harvested from inside the tree canopy. These results are consistent with our understanding of melanose biology.

The most notable treatment effect in 1998 was increased melanose scores and greater anticipated fruit cullage on trees receiving four airblast applications of $\mathrm{Cu}(\mathrm{OH})_{2}$. The only trees with mean melanose scores not significantly lower, were those receiving an airblast spray treatment 5.5 weeks postbloom.

In 1999-2000, the trees receiving four airblast applications of $\mathrm{Cu}(\mathrm{OH})_{2}$ had significantly lower melanose scores and percentage of fruit exceeding cullage thresholds than the trees receiving no airblast spray or airblast spray only at bloom. Trees receiving four airblast applications also had significantly lower mean melanose scores than trees receiving airblast sprays at only 3 or 5.5 weeks postbloom. In this year, there was a strong trend of improved fruit melanose control with later airblast applications of $\mathrm{Cu}(\mathrm{OH})_{2}$, even though significant rains occurred at fairly regular intervals throughout the study period. Whiteside (1988) noted that conditions in Florida are usually too dry for significant melanose infection during the first 4 to 6 weeks after petal fall, but unusual wet weather occasionally permits substantial infection of Indian River grapefruit during this period (Indian River growers, personal communication) and growers feel that early prophylactic $\mathrm{Cu}(\mathrm{OH})_{2}$ sprays provide valuable insurance against this disease.

Melanose control by aerial $\mathrm{Cu}(\mathrm{OH})_{2}$ application cannot be assessed using this experimental design, which was primarily intended to test the effects of airblast equipment on windscar without leaving an entire commercial block unprotected by fungicides. However, fruit melanose was present in the study orchard, with only $50 \%$ of interior fruit suitable for export sales (melanose score <2) across all treatments, so we can assess the value of supplementing aerial coverage with sprays delivered through airblast. In 1998, no application timing using tractor-drawn equipment significantly reduced the level of melanose compared to fruit treated solely via aircraft, in interior fruit (data not shown) as well as for all sample positions combined (Table 4). In 1999-2000, both treatments that included airblast application at 8 weeks postbloom decreased cullage resulting from melanose damage, providing a packable fruit increase of $7 \%$ to $13 \%$ of the total sample compared to trees receiving only aerial fungicide applications (Table 5). In this study it appeared that only modest supplementation of aerial application using tractor-drawn equipment may be necessary to get good commercial control of melanose. However, deficiencies following aerial coverage may be more evident with higher inoculum levels and environmental conditions more favorable for disease development. Nonetheless, further work on complementary use of aerial and ground-delivered application appears to be advisable, since the low cost of aerial application $(\$ 19 /$ ha vs. $\$ 78 /$ ha for airblast application at $2300 \mathrm{~L} \cdot \mathrm{ha}^{-1}$; Muraro et al., 2001) makes frequent coverage with lower rates of pesticides feasible.

\section{Literature Cited}

Albrigo, L.G. 1976. Influence of prevailing wind and hedging on citrus fruit wind scar. Proc. Fla. State Hort. Soc. 89:55-59.

Bullock, R. C., R.F. Brooks, and D.V. Calvert. 1977. Comparison of low volume citrus spray programs applied by aircraft and airblast sprayer in Florida. Proc. Fla. State Hort. Soc. 90:10-13.

Dodson, P.G.C. 1966. Damage to citrus fruits by wind. S. Afr. Citrus J. 393:4-7, 11

FAWN. 2002. Florida automated weather network. http://fawn.ifas.ufl.edu/.

Kucharek, T.A and G.E. Brown. 1992. Melanose. Univ. Fla. Ext. Fact Sheet PP-150.

Lin, N., H. Beck, F. Zazueta, G. Albrigo, A. Wheaton, B. Castle, R. Peart, J. Valiente, D. Martsolf, J. Ferguson, and P. Spyke. 1999. Decision information systems for citrus: Software implementation and testing. Proc. Fla. State Hort. Soc. 112:40-43.

McPhee, J. 1966. Oranges. Farrar, Straus, and Giroux, New York.

Metcalf, W. 1936. The influence of windbreaks in protecting citrus orchards. J. For. 34:571-580.

Miller, W.M and J.K. Burns. 1992. Grade lowering defects and grading practices for Indian River grapefruit. Proc. Fla. State Hort. Soc. 105:129-130.

Muraro, R.P., J.W. Hebb, and E.W. Stover. 2001. Budgeting costs and returns for Indian Rive citrus production, 2000-2001. IFAS Econ. Info. Rpt. EI 01-07.

Salyani, M., Y.M. Koo, and R.Y. Sweeb. 2000. Spray application variables affect air velocity and deposition characteristics of tower sprayers. Proc. Fla. State Hort. Soc. 113:96-101.

Stover, E., J. Salvatore, and P. McClure. 2002a. Influence of spray volume, ground speed, and sensor-actuated spray manifolds on pest control in fresh grapefruit. Proc. Fla. State Hort. Soc. 115:1-5

Stover, E., D. Scotto, and J. Salvatore, 2002b. Pesticide spraying in Indian River grapefruit: I. Survey of current practices. HortTechnology 12:454-460.

Timmer, L.W. 2001.2001 Florida citrus pest management guide: melanose. Univ. Fla. Ext. Fact Sheet PP-145. http://edis.ifas.ufl.edu/CG019.

Timmer, L.W., S.E. Zitko, and L.G. Albrigo. 1998 Split applications of copper fungicides improve control of melanose on grapefruit in Florida. Plant Dis. 82:983-986.

Valco, T.D and H. O'Neal. 2002. Texas citrus: Orchard spraying. http://aggie-horticulture. tamu. edu/citrus/12293.htm.

Whiteside, J.O. 1988. Melanose, p. 20-21. In: J.O. Whiteside, S.M. Garnsey, and L.W. Timme (eds.). Compendium of citrus diseases. APS Press, St. Paul, Minn. 